Food, Dairy and Home Economic Research

http:/www.journals.zu.edu.eg/journalDisplay.aspx?Journalld=1\&queryType=Master

\title{
CHEMICAL AND FUNCTIONAL PROPERTIES OF GARDEN CRESS (Lepidium sativum L.) SEEDS POWDER
}

\author{
Kholoud H. Abd El-Salam*, A.O. Toliba, Gehan A. El-Shourbagy and Sh.E. El-Nemr \\ Food Sci. Dept., Agric. Fac., Zagazig Univ., Egypt
}

Received: 04/07/2019; Accepted: 28/07/2019

\begin{abstract}
Garden cress (Lepidium sativum) is a rapidly increasing yearly herb that grow in Egypt and West Asia countries, although now grown around the globe. The herp is often known as garden cress (GC). Their seeds have a wealth of protein, fiber, omega-3 acids, iron and other vital nutrients. The chemical composition, minerals contents, phenolic compounds, flavonoids, antioxidant activity and functional properties of GC seeds powder were investigated. The results revealed that GC seeds powder contained $7.05 \%$ moisture, $19.73 \%$ crude protein, $14.18 \%$ crude fat, $35.45 \%$ carbohydrate, $18.79 \%$ crude fibers and $4.8 \%$ ash. In addition, potassium $(2955.50 \mathrm{mg} / 100 \mathrm{~g})$ was the most abundant element in GC seeds followed by phosphorus (947.32 mg/100g) and magnesium $(322.00 \mathrm{mg} / 100 \mathrm{~g})$. The extract of GC seeds had a $157.24 \mathrm{mg} / \mathrm{g}$ of total phenols and $75.01 \mathrm{mg} / \mathrm{g}$ of total flavonoids. Gallic acid and hisperidin were the most abundant phenolic and flavonoid compounds in GC seed extract being 3001.75 and $4934.99 \mu \mathrm{g} / 100 \mathrm{~g}$, respectively. After $120 \mathrm{~min}$ of DPPH tests, the antioxidant activity of GC extract achieved $89.75 \%$. The ability of GC seeds to water holding capacity (WHC) was $4.51 \mathrm{ml} / \mathrm{g}, 2.79 \mathrm{ml} / \mathrm{g}$ for oil holding capacity (OHC) with $44.54 \%$ of emulsifying activity (EA). It could be conducted that GC seeds are recommended in order to enhance nutritional quality and functional properties as food supplementation.
\end{abstract}

Key words: Lepidium sativum, chemical composition, phenolics, flavonoids, functional properties, garden cress.

\section{INTRODUCTION}

Garden cress (GC), scientific name: Lepidium sativum L., is an annual herb, belonging to family Brassicaceae (Sharma and Agarwal, 2011). It is a fast-growing, edible plant botanically related to watercress and mustard and sharing their peppery, tangy flavour and aroma (Balasubramanian, 2009). Bigoniya et al. (2011) reported that, GC seeds are small, oval-shaped, pointed and triangular at one end, smooth, about 3-4 $\mathrm{mm}$ long, 1-2 $\mathrm{mm}$ wide, reddish brown in colour. Seeds, leaves and roots are economically important, however, the crop is mainly cultivated for seeds. In some regions garden cress is known as garden pepper cress, pepper grass or garden pepper cress, pepper grass or chandrasur in India and it is an important chandrasur in India and it is an important medicinal crop in India (Doke and Guha, 2014). The main character of GC is that it can grow in any type of climate and soil condition with few requirements (Balasubramanian, 2009). It is also known as important medicinal crop in India. GC is indigenous to Egypt and south west Asia and was referred to over many centuries ago in Western Europe (Sharma and Agarwal, 2011; Doke and Guha, 2014). Garden cress is a annual plant, and an important green vegetable consumed by human beings, most typically as a garnish or as a leaf vegetable. (Tiwari and Kulmi, 2004). A furrow present on both surfaces extending up to two thirds downward, a slight wing like extension present on both the edges of seed. On soaking in water seed coat swells and gets covered with

\footnotetext{
*Corresponding author: Tel. : +201276097272

E-mail address: kholod12hatem@gmail.com
} 
transparent, colorless, mucilage with mucilaginous taste.

GC seed is a special seed used in special food preparations given to girls at menarche and after delivery in traditional Indian foods. It is rich in iron $(100 \mathrm{mg} / 100 \mathrm{~g})$ and also contains several nutraceutical components. The seeds possess fair levels of protein (21-25\%), fat (23$27 \%)$, carbohydrate (30-34\%), dietary fiber (30\%), phosphorus (723 mg/100 g), magnesium $(430 \mathrm{mg} / 100 \mathrm{~g})$, calcium $(296-377 \mathrm{mg} / 100 \mathrm{~g})$, iron $(76-100 \mathrm{mg} / 100 \mathrm{~g})$, zinc $(5 \mathrm{mg} / 100 \mathrm{~g})$ and thus an important nutraceutical seed for nutrient enrichment (Sood and Sharada, 2002; Gokavi et al., 2004; Gopalan et al., 2011; Sharma and Agarwal, 2011; Zia-Ul-Haq et al., 2012; Mohite et al., 2012; Mohammed, 2012; Shail et al., 2016; Doke and Guha, 2017). The most abundant amino acid in GC protein is glutamic acid $(19.3 \%)$ and among the essential amino acid, leucine, is the highest $(8.21 \%)$ and methionine, is the lowest $(0.97 \%)$ (Sharma and Agarwal, 2011).

Sarkar et al. (2014) reported that garden cress seed is categorized under nuts and oil seeds. GC oil is considered to be fairly stable oil, since its component natural antioxidants (tocopherol, phytosterol, and carotenoids) protect the oil from rancidity (Diwakar et al., 2010). The primary fatty acids in GC seed oil were oleic (22-30.6\%) and linolenic acids (29-34\%) and was found to contain high concentrations of tocopherols. It contains good amount of lignans and antioxidants, which can stabilize the n-3 polyunsaturated fatty acids in its seed oil. The primary phytosterols in Lepidium sativum were sitosterol and campesterol, with avenasterol (Diwakar et al., 2008; Bryan et al., 2009; Sharma and Agarwal (2011)). GC seed oil is a rich source of omega-3-fatty acids $(30 \%)$ and natural antioxidant tocopherol $(139 \mathrm{mg} / 100 \mathrm{~g})$ and carotenoid (1.0 $\mu \mathrm{g} / 100 \mathrm{~g}$ oil) (Gokavi et al., 2004; Diwakar et al., 2010). GC seed also contains sufficient amount of vitamins, mainly thiamine $(0.59 \mathrm{mg})$, riboflavin $(0.61 \mathrm{mg})$ and niacin $(14.3 \mathrm{mg})$. These vitamins work as a co-factor and help in body metabolism (Gopalan et al., 2011).

Alkaloids, flavonoids, cardiotonic glycosides, glucosinolates, sterols, tannins, and triterpenes are important phytochemical constituents, which impart pharmacological characteristics to GC seed (Ghante et al., 2011). Total polyphenol and total flavonoid content of ethanolic extract of Lepidium sativum L. seeds were 4.46-8.651 $\mathrm{mg}$ gallic acid equivalent (GAE)/g and 3.57$4.023 \mathrm{mg}$ quercetin equivalent (QE)/g, respectively (Yadav et al., 2011; Indumathy and Aruna, 2013). The antioxidant properties depend on the phenolic compounds present in garden cress seeds (Ait-Yahia et al (2018).

Tocopherols are the major phenolic compounds in GC extracts. Tocopherols are biological radical scavengers that prevent oxidation of oil. In addition to having a major human nutritional function as a vitamin $\mathrm{E}$ source, tocopherols also prevent illnesses (Brigelius et al., 2002; Jeong et al., 2004; Dandge et al., 2012; Jain and Grover, 2017).

Sharma and Agarwal (2011) reported that garden cress seed's bran has a high water holding capacity due to high dietary fiber content $(74.3 \%)$. GC seeds protein isolate contains $86.90 \%$ protein and has high water absorption capacity of $229 \mathrm{ml} \mathrm{H}_{2} \mathrm{O} / 100 \mathrm{~g}$ and oil absorption capacity of $3.5 \mathrm{ml} \mathrm{oil} / \mathrm{g}$, that makes it a potential ingredient in meat, bread and cakes industries and can be used as a nutrient substitution or supplementation and also act as a functional agent in food systems (Ali, 2013). Tuncay et al. (2011) and Gaafar et al. (2013) reported that $L$. sativum seeds with high nutritional value can be exploited as a functional food ingredient. The seeds are consumed either raw or processed (soaked, boiled and roasted) forms. The different processing improves shelf life as well as acceptability of food. Processing techniques affect the nutritive value of oil seed (Arinola and Adesina, 2014).

The objective of this research consisted of assessing the GC seeds as food supplements in relation to: its chemical composition, phenolic compounds, flavonoids, antioxidant activity and functionality.

\section{MATERIALS AND METHODS}

\section{Materials}

Garden cress seeds were purchased from local market, Zagazig city, Sharkia Governorate, Egypt. The seeds were cleaned and rendered free of dust, dirt, foreign materials and broken 
seeds. All chemicals and reagents were of the analytical grade and purchased from Elgomhurya Company, Zagazig Branch, Egypt.

\section{Methods}

\section{Preparation of garden cress seeds extract}

Garden cress seed powder was prepared by grinding the seeds (Moulinex A59, France). Sieving process with 40 mesh sizes used to sieve the end product. The seed powder was extracted with ethanol $(70 \%)$, at a ratio of $1: 10(W / V)$, in closed vessels by magnitic stirring $(250 \mathrm{rpm})$ at room temperature $\left(25 \pm 2^{\circ} \mathrm{C}\right)$ for $4 \mathrm{hr}$., followed by filtration through Whatman No 1 filter paper. The residues were re-extracted again under the same conditions. All vessels were wrapped with aluminum foil to prevent light degradation during extraction (Yu et al., 2005).

\section{Chemical composition of garden cress seeds}

The major chemical constituents, moisture, crude protein, crude fat, crude fiber and ash in GC seeds were determined in triplicate according to AOAC (2005). Carbohydrate content was calculated by differences follows: 100 - (\% ash + protein + fat + moisture $)$. These assays were conducting in Central Laboratory, Faculty of Agriculture, Zagazig University, Egypt.

\section{Determination of minerals contents}

Minerals contents in GC seeds Potassium $(\mathrm{K})$, Phosphorus $(\mathrm{P})$, Magnesium $(\mathrm{Mg})$, Sodium $(\mathrm{Na})$, Calcium $(\mathrm{Ca})$, Iron $(\mathrm{Fe})$, Zinc $(\mathrm{Zn})$, Manganese $(\mathrm{Mn})$, Copper $(\mathrm{Cu})$, Lead $(\mathrm{Pb})$, Chromium ( $\mathrm{Cr}$ ), Cobalt (Co), Bromine (Br), Selenium (Se), Cadmium (Cd) and Nickel (Ni) were determined according to the method of AOAC (2005) using atomic absorption spectrophotometer (ICAP 6500 Duo, England Multi-element certified standard solution 100 $\mathrm{mg} / \mathrm{l}$ Merk, Germany) at the Central Laboratory, Faculty of Agriculture, Zagazig University, Egypt.

\section{Determination of total phenolic compounds (TPC)}

The concentration of TPC in GC seed extract was measured using UV spectrophotometer (Jenway-UV-VIS Spectrophotometer), based on a colorimetric oxidation/reduction reaction, as described by Škerget et al. (2005) using FolinCiocalteu reagent. Specifically, $0.5 \mathrm{ml}$ of diluted extract (10 mg in $10 \mathrm{ml}$ solvent) was mixed with $2.5 \mathrm{ml}$ of Folin-Ciocalteu reagent (diluted 10 times with distilled water) and $2 \mathrm{ml}$ of $\mathrm{Na}_{2} \mathrm{CO}_{3}$ $(75 \mathrm{~g} / \mathrm{l})$. The sample was incubated for $5 \mathrm{~min}$ at $50^{\circ} \mathrm{C}$ then cooled. For a control sample, $0.5 \mathrm{ml}$ of distilled water was used. The absorbance was measured at $760 \mathrm{~nm}$. Total phenolic content expressed as gallic acid equivalent (GAE) was calculated, and the results were expressed as an mg GAE/g extract. Total phenolic content expressed as gallic acid equivalent (GAE) was calculated using the following linear equation based on the calibration curve:

$$
\mathrm{Y}=0.015 \mathrm{x}+0.0533 ; \mathrm{R}^{2}=0.9966
$$

Where:

$\mathrm{Y}$ is the absorbance and $\mathrm{x}$ is the concentration (mg GAE /g extract).

$\mathrm{R}^{2}=$ correlation coefficient. This assay was conducting in Agricultural Res. center laboratory, Cairo, Egypt.

\section{Determination of total flavonoid compounds (TFC)}

The content of flavonoids in the examined GC seed extract was determined using spectrophotometric method (Quettier et al., 2000). The sample contained $1 \mathrm{ml}$ of methanol solution of the extract in the concentration of 1 $\mathrm{mg} / \mathrm{ml}$ and $1 \mathrm{ml}$ of $2 \% \mathrm{AlCl}_{3}$ solution dissolved in methanol. The samples were incubated for an hour at room temperature. The absorbance was determined using spectrophotometer at $\lambda \max =$ $415 \mathrm{~nm}$. The samples were prepared in triplicate for each analysis and the mean value of absorbance was obtained. The same procedure was repeated for the standard solution of rutin and a dilution series of rutin of concentrations $0.01,0.02,0.03,0.04$ and $0.05 \mathrm{mg} / \mathrm{ml}$ was prepared and the calibration line was construed. Based on the measured absorbance, the concentration of flavonoids was read $(\mathrm{mg} / \mathrm{ml})$ on the calibration line; then, the content of flavonoids in the extracts was expressed in terms of rutin equivalent ( $\mathrm{mg}$ of RU/g of extract).

\section{Fractionation of Phenolic and flavonoid compounds}

The phenolic and flavonoid compounds of GC extract were determined in Central Laboratory 
of Food Technol. Res. Inst., Agric. Res. Center, Giza, Egypt. An HP1100 HPLC system equipped with an alpha bond C 18 125A column (4.6.250 $\mathrm{mm}$, particle size $5 \mu \mathrm{m}$ ) and coupled with agilent 1100 series Chem. Station software was used for quantifying the individual phenolic acids. The mobile phases consisted of $2.0 \%$ acetic acid in distilled water (A) and acetonitrile (B). The column was eluted at $1 \mathrm{ml} / \mathrm{min}$ under a linear gradient from 5\% mobile phase B to $75 \%$ over $20 \mathrm{~min}$, to $100 \%$ over $5 \mathrm{~min}$. Sample injection volumes were $20 \mu 1$. Compounds were detected at $280 \mathrm{~nm}$ and $330 \mathrm{~nm}$ for phenolic and flavonoid compounds with an HP1100 series ultraviolet (UV) diode array detector. Standards obtained from Sigma Co. were dissolved in a mobile phase and injected into HPLC. Retention time and peak area were used to calculation of phenolic and flavonoid compounds concentration by the data analysis of HEWLLET packared software, according to Goupy et al. (1999).

\section{Determination of antioxidant activity of GC extracts}

Radical scavenging activity (RSA) of GC seed extracts was measured by bleaching of the purple coloured solution of DPPH according to the method of Hanato et al. (1988). One hundred $\mu \mathrm{l}$ of each extracts $(10 \mathrm{mg}$ extract $/ 10 \mathrm{ml}$ solvent) was added to $3 \mathrm{ml}$ of $0.1 \mathrm{mM}$ DPPH dissolved in ethyl acetate and ethanol according to the solvent used for extraction. After 30, 60 and $120 \mathrm{~min}$ incubation period at room temperature, the absorbance was estimated against a control at $517 \mathrm{~nm}$ (Gulcin et al., 2004). Percentage of antioxidant activity of free radical DPPH was calculated as follows:

DPPH scavenging activity $(\%)=\left[\left(\mathrm{A}_{0}-\mathrm{A}_{1}\right) /\right.$ $\left.A_{0}\right] \times 100$, where, $A_{0}$ is the absorbance of the control reaction and $A_{1}$ is the absorbance in the extract. Samples were analyzed in triplicate.

\section{Determination of water-holding capacity (WHC)}

WHC was measured after centrifugation of the water insoluble residues according to Chau and Huang (2003) with slight modifications. Samples (1g) were hydrated in excess $20 \mathrm{ml}$ distilled water at room temperature for $1 \mathrm{hr}$., prior to centrifugation at $1200 \times \mathrm{g}$ for $30 \mathrm{~min}$ (Model D-3750, SIGMA, Germany). Excess supernatant was decanted. WHC was calculated as the amount of water retained by the sample ( $\mathrm{ml}$ water/g dry weight).

\section{Determination of oil-holding capacity (OHC)}

OHC was measured according to Garau et al. (2007) with some modification. Powder samples $(1 \mathrm{~g})$ were mixed with olive oil $(20 \mathrm{ml})$, centrifuged at $1200 \times \mathrm{g}$ for $30 \mathrm{~min}$ and the excess supernatant was decanted. OHC was expressed as $\mathrm{ml}$ oil/g dry weight.

\section{Emulsifying capacity and stability}

Emulsifying capacity and stability were determined using the method of Neto et al. (2001). Five milliliters of garden cress seeds powder suspension $(2 \% W N)$ were homogenized with $5 \mathrm{ml}$ corn oil. The emulsions were centrifuged at $1100 \times \mathrm{g}$ for $5 \mathrm{~min}$. The height of emulsified layer and that of total contents in the tube was measured.

The emulsifying capacity (EC) was calculated as:

$\mathrm{EC}(\%)=\frac{\text { Height of emulsified layer in the tube }}{\text { Height of the total content in tube }} \times 100$

Emulsion stability was determined by heating the emulsion at $80^{\circ} \mathrm{C}$ for $30 \mathrm{~min}$ before centrifuging at $2200 \mathrm{rpm}$ for $5 \mathrm{~min}$.

ES(\%) $=\frac{\text { Height of emulsified layer after heating }}{\text { Height of emulsified layer before heating }} \times 100$

Determination of foaming capacity and stability

Foaming capacity and stability of the samples were studied at different $\mathrm{pH}$ values (4, 5, 6 and 7) according to the method of Sathe and Salunkhe (1981). One gram of the sample was whipped with $100 \mathrm{ml}$ of citrate phosphate buffer at $\mathrm{pH} \mathrm{4,} \mathrm{5,} 6$ and 7 for 5 min using Universal Laboratory aid Mixer (Type 309, Poland) at speed setting 150 and was pound into a $250 \mathrm{ml}$ cylinder. The total volume recorded at time intervals of $0.0,0.5,1.0,1.5,2.0,2.5,3.0$ $\mathrm{hrs}$ as foam stability. Volume increase (\%) was calculated according to the following equation: volume increase $(\%)=(a-b) / b \times 100$, where: $a=$ volume after whipping, $b=$ volume before whipping.

\section{Standard deviation determination}

Tests were conducted in triplicate and the means were recorded. The standard deviation of obtained results was calculated as described by a 
statistical for social science package "SPSS" version 20 for Microsoft windows according to Dominick and Derrick (2001).

\section{RESULTS AND DISCUSSION}

\section{Chemical Composition}

The chemical composition of GC seeds is presented in Table 1. GC seeds powder contained $7.05 \%$ moisture, $19.73 \%$ crude protein, $14.18 \%$ crude fat, $35.45 \%$ carbohydrate, $18.79 \%$ crude fiber and $4.8 \%$ ash. These results show that the macronutrients are considerably high and suitable for human nutrition. In addition, the above findings are almost in accordance with the outcomes reported by Zia-Ul-Haq et al. (2012), Mohammed (2012) and Doke and Guha (2017). Mohammed (2012), reported that the garden cress seeds contain $25 \%$ of protein, $14-$ $24 \%$ of lipids, $33-54 \%$ of carbohydrates and $8 \%$ of crude fiber. Zia-Ul-Haq et al. (2012) observed the proximate chemical compositions the moisture $2.9 \%$, crude protein $24.2 \%$, crude fat $23.2 \%$, carbohydrate $30.7 \%$, crude fiber $11.9 \%$, ash $7.1 \%$.

\section{Minerals Content}

Minerals contents of GC seeds are shown in Table 2. The most abundant element in GC seeds was potassium $(2955.50 \mathrm{mg} / 100 \mathrm{~g})$ followed by phosphorus $(947.32 \mathrm{mg} / 100 \mathrm{~g})$ and magnesium $(322.00 \mathrm{mg} / 100 \mathrm{~g})$. In addition, it contained remarkable levels of sodium and calcium. GC seeds are free from bromine, selenium, cadmium and nickel. Shail et al. (2016) and Doke and Ghua (2017) reported that GC seeds are a good source of minerals such as potassium, phosphorus and magnesium.

\section{Total Phenolic and Total Flavonoid Compounds}

The yield of garden cress seeds extract was $11.24 \mathrm{~g} / 100 \mathrm{~g}$. These results are in harmony with those reported by Abo El-Maati et al. (2016) and Malar et al. (2014). Variation in the yields of extracts is attributed to differences in polarity of compounds present in plants and assist methods, such differences have been reported (Jayaprakasha et al., 2001). To obtain acceptable yields with minimal changes of functional properties of the extract required, the extraction technique is one of the most important stage (Zhu et al., 2011).

Phytochemicals from plants are being used for prevention from various diseases mainly caused by free radicals. The higher polyphenol content would then exhibit stronger inhibition and also higher antioxidant activity (Prakasha et al., 2001). The results presented showed that ethanolic extract of GC seeds had $1572.4 \mu \mathrm{g} / \mathrm{g}$ total phenols. These results agree with that reported by Zia-Ul-Haq et al. (2012) and AitYahia et al. (2018). The technique of phenolic isolation from a plant material, including the methods and type of extracting solvent, depends generally on the type of phenolic compound and the solvents (Goli et al., 2005). On the other hand, ethanolic GC seeds extract had $750.1 \mu \mathrm{g} / \mathrm{g}$ of total flavonoids. These results are in agreement with that reported by Zia-Ul-Haq $\boldsymbol{e t}$ al. (2012) and Ait-Yahia et al. (2018).

Phenolic compounds are very important plant constituents because of their scavenging ability due to their hydroxyl groups (Oktay et al., 2003). HPLC results displayed in Table 3 indicate that 21 phenolic compounds have been quantified in GC seed extract. Gallic acid and Protocatechuic acid are phytochemicals that are considered a potential source of functional food ingredients for their high antioxidant capacity (Sethiya et al., 2014). Gallic acid (3001.75 $\mu \mathrm{g} /$ $100 \mathrm{~g}$ ) was the main phenolic compound followed by ellagic $(1460.80 \mu \mathrm{g} / 100 \mathrm{~g})$ and protocatechuic $(582.23 \mu \mathrm{g} / 100 \mathrm{~g})$. In addition, pyrogallol was found at the lowest level of 6.29 $\mu \mathrm{g} / 100 \mathrm{~g}$ as given in Table 3 . The obtained results are similar to those reported by Zia-Ul-Haq $\boldsymbol{e t}$ al. (2012) and Panwar and Guha (2014).

The current research has found that nineteen flavonoid compounds were quantitatively identified in GC seeds extract as shown in Table 4. The Hisperidin was the major component and it showed $4934.99 \mu \mathrm{g} / 100 \mathrm{~g}$. Quercetin, another phytochemical in the seed, is a flavonoid that has attracted great interest because it is a potent antioxidant with proven anticancer effects. Its structure contains a double bond in the $\mathrm{C}$ ring and a 4-oxo group, which enhance its antioxidant activity (Moskaug et al., 2004). 
Table 1. Chemical composition of garden cress seeds powder

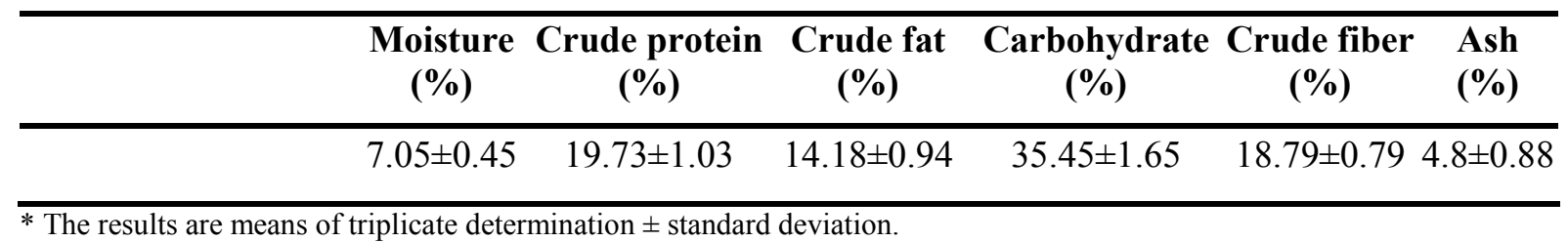

Table 2. Mineral contents of garden cress seeds powder

\begin{tabular}{lcc}
\hline Element & $\mathbf{( m g} / \mathbf{1 0 0 g})$ & $\mathbf{( \% )}$ \\
\hline Potassium (K) & 2955.50 & 63 \\
Phosphorus (P) & 947.32 & 20 \\
Magnesium (Mg) & 322.00 & 6.9 \\
Sodium (Na) & 229.35 & 4.9 \\
Calcium (Ca) & 203.23 & 4.3 \\
Iron (Fe) & 6.50 & 0.13 \\
Zinc (Zn) & 2.95 & 0.06 \\
Manganese(Mn) & 1.94 & 0.04 \\
Copper (Cu) & 0.77 & 0 \\
Lead (pb) & 0.61 & 0 \\
Chromium (Cr) & 0.36 & 0 \\
Cobalt (Co) & 0.01 & 0 \\
\hline
\end{tabular}

Table 3. Phenolic compounds in garden cress seeds extract

\begin{tabular}{lcc}
\hline Phenolic compound & $(\boldsymbol{\mu g} / \mathbf{1 0 0 g})$ & $\mathbf{( \% )}$ \\
\hline Gallic & 3001.75 & 34.3 \\
Pyrogallol & 6.29 .00 & 0.07 \\
4-Aminobenzoic & 127.85 & 1.45 \\
Protocatechuic & 582.23 & 6.65 \\
Catechein & 107.61 & 1.22 \\
Chlorogenic & 552.75 & 6.30 \\
Catechol & 173.74 & 1.97 \\
Caffiene & 212.55 & 2.42 \\
P.oH. benzoic & 27.85 & 0.30 \\
Caffeic & 245.30 & 2.80 \\
Vanillic & 422.79 & 4.82 \\
p-Coumaric & 113.86 & 1.29 \\
Ferulic & 78.40 & 0.89 \\
Iso- ferulic & 540.34 & 6.17 \\
Ellagic & 1460.80 & 16.6 \\
Benzoic & 275.76 & 3.14 \\
$\boldsymbol{\alpha}-$ Coumaric & 36.77 & 0.41 \\
3,4,5.Methoxy Cinnamic & 82.03 & 0.93 \\
Coumarin & 517.52 & 5.91 \\
Salicylic & 72.20 & 0.82 \\
Cinnamic & 111.9567 & 1.28 \\
Total & 1572.40 & 8750.34 \\
\hline
\end{tabular}


Table 4. Flavonoid compounds in garden cress seeds extract

\begin{tabular}{lcc}
\hline Flavonoid & $(\boldsymbol{\mu g} / \mathbf{1 0 0 g})$ & $(\mathbf{\%})$ \\
\hline Apig.6-arbinose 8-glactose & 629.98 & 4.68 \\
Apig.6-rhamnose 8-glucose & 684.40 & 5.09 \\
Narengin & 963.79 & 7.17 \\
Rutin & 1216.72 & 9.05 \\
Hisperdin & 4934.99 & 36.7 \\
Quercitrin-3-o-glucose & 269.71 & 2.00 \\
Rosmarinic & 516.27 & 3.84 \\
Apig.7-o-neohespiroside & 282.19 & 2.09 \\
Quercitrin & 1520.33 & 11.3 \\
APigenin-7-glucose & 288.43 & 2.14 \\
Kaemp.3-(2-pcomaroyl)glucose & 1286.89 & 9.57 \\
Quercitrin & 97.39 & 0.72 \\
Acacetin 7neo hesperside & 66.15 & 0.49 \\
Narengin & 142.98 & 1.05 \\
Hispertin & 142.74 & 1.05 \\
Acacetin neo.rutinoside & 184.95 & 1.37 \\
Rhamentin & 129.77 & 0.96 \\
Apegnin & 14.62 & 0.10 \\
Kampferol & 58.05 & 0.43 \\
Total & 750.10 & 13429.3 \\
\hline
\end{tabular}

The scavenging activity of GC seeds extracts against DPPH at 0, 30, 60, 90 and 120 min of incubation is represented in Table 5. The antioxidant activity of GC seed extract at the beginning of the incubation was $79.18 \%$ and this value reached $89.75 \%$ after $120 \mathrm{~min}$. The results are found to be in agreement with those reported by Abo El-Maati et al. (2016). In general, the extracts that contained the high amount of total phenolic compounds showed relatively high antioxidant activity and it has been proven that the antioxidant activity of extracts is mainly ascribable to the concentration of phenolic compounds in the plant (Heim et al., 2002).

\section{Functional Properties}

The WHC is commonly related to the amount of water in the fiber equilibrated in an environment of known water potential and absorbed by a capillary suction mechanism (Namir et al., 2015). Table 6 shows the WHC, OHC, emulsifying capacity and stability. Results showed that GC seed extract absorbed $4.51 \mathrm{ml} / \mathrm{g}$ water and $2.79 \mathrm{ml} / \mathrm{g}$ oil. Furthermore, emulsifying activity and stability of GC seeds were 44.54 and 40.65, respectively. Ali (2013) reported that GC seeds protein isolate contains $86.90 \%$ protein and has water absorption capacity of 229 $\mathrm{ml} \mathrm{H} \mathrm{H}_{2} \mathrm{O} / 100 \mathrm{~g}$ and oil absorption capacity of 3.5 $\mathrm{ml} \mathrm{oil} / \mathrm{g}$, that makes it a potential ingredient in meat, bread and cakes industries and can be used as a nutrient substitution or supplementation and also act as a functional agent in food systems.

Foaming capacity and stability of GC seeds were illustrated in Figs. 1 and 2, respectively. The activity of foaming increased $25 \%$ by increasing $\mathrm{pH}$ value to $\mathrm{pH} 7$. On the other hand, foaming stability was decreased during time intervals reached $2.5,5$ and $10 \%$ after $2 \mathrm{hr}$., at $\mathrm{pH} 4,5$ or 6 and 7, respectively.

\section{Conclusion}

It could be concluded that GC seeds have significant content of microelements, phenolic and flavonoids, along with excellent functional characteristics, which can be used as a food supplement and functional agent. 
Table 5. DPPH radical scavenging (\%) of garden cress seeds extract during incubation time (min)

\begin{tabular}{llcccc}
\hline & \multicolumn{5}{c}{ Incubation time (min) } \\
\cline { 2 - 5 } & Zero & $\mathbf{3 0}$ & $\mathbf{6 0}$ & $\mathbf{9 0}$ & $\mathbf{1 2 0}$ \\
\hline DPPH inhibition (\%) & $79.18 \pm 1.05$ & $87.32 \pm 0.97$ & $88.37 \pm 1.43$ & $88.59 \pm 1.74$ & $89.75 \pm 0.99$ \\
\hline * The results are means of triplicate determination \pm standard deviation. & & \\
& & & \\
Table 6. Water, oil holding capacity, emulsifying activity and stability of GC seeds powder \\
\hline Functional property & \multicolumn{3}{c}{ Value } \\
\hline Water holding capacity (ml/g) & $4.51 \pm 0.83$ \\
Oil holding capacity (ml/g) & $2.79 \pm 0.32$ \\
Emulsifying activity (\%) & $44.54 \pm 1.35$ \\
Emulsifying stability (\%) & $40.65 \pm 1.02$ \\
\hline
\end{tabular}

* The results are means of triplicate determination \pm standard deviation.

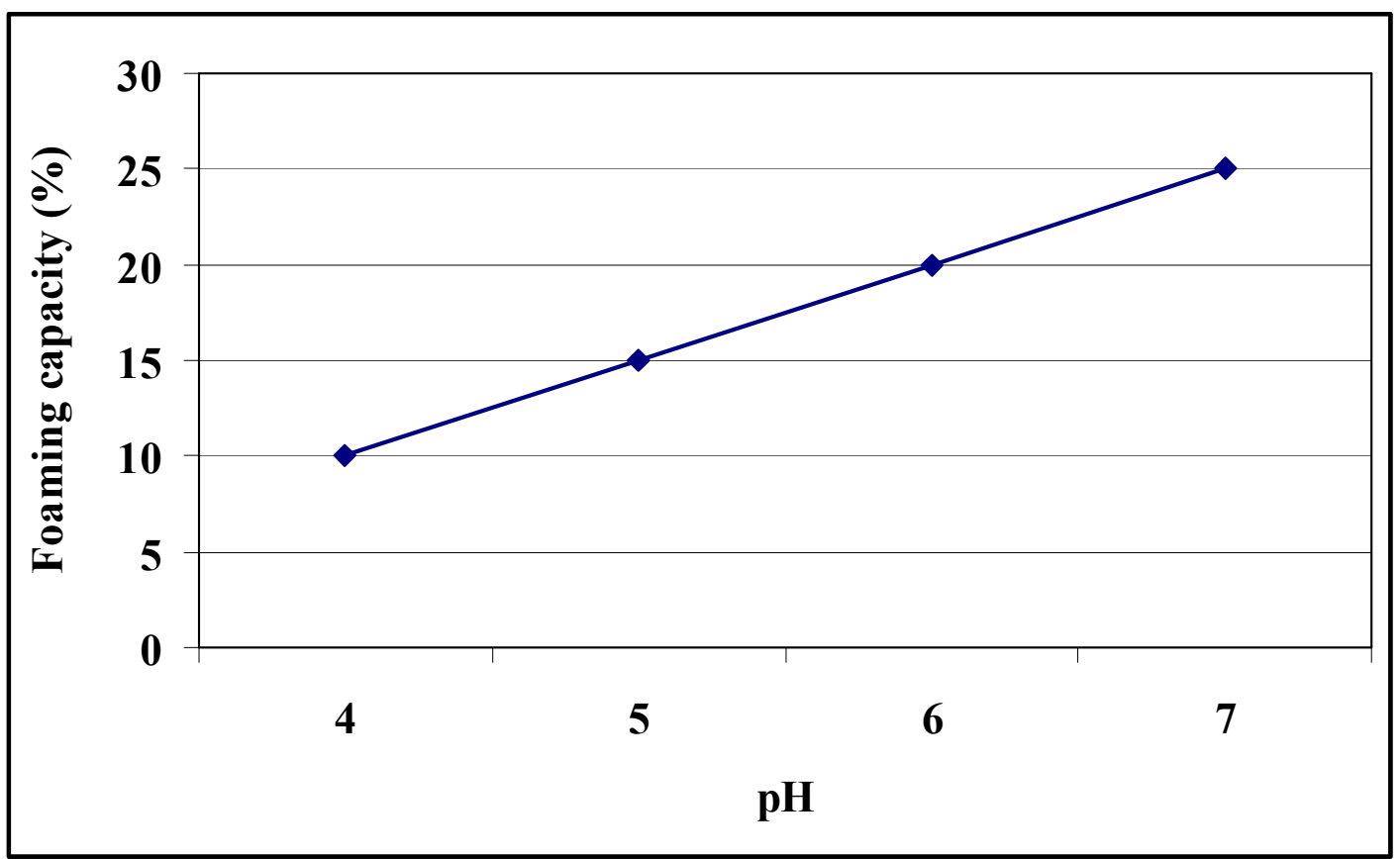

Fig. 1. Foaming capacity (\%) of GC seeds powder as a function of $\mathrm{pH}$ 


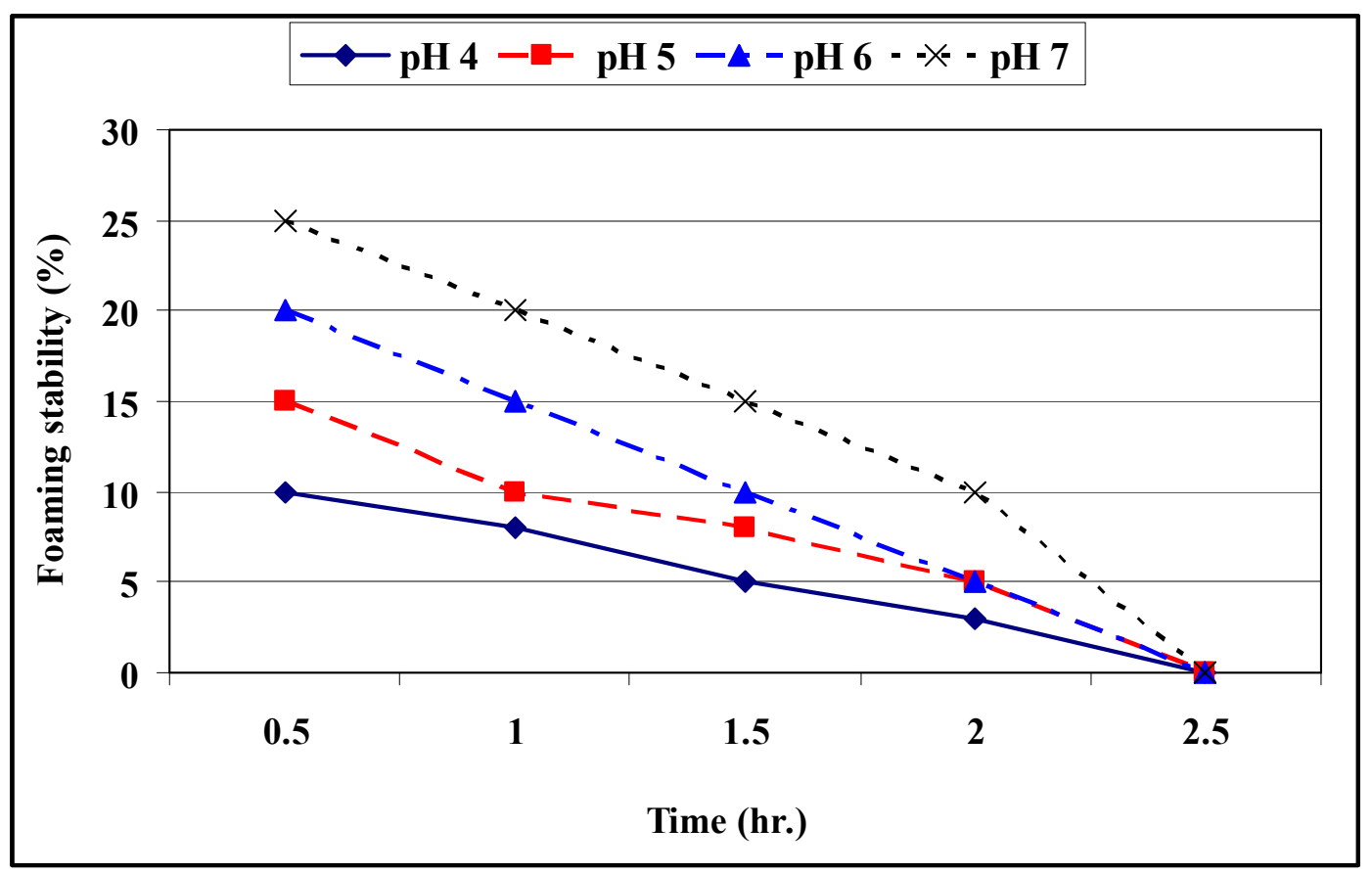

Fig. 2. Foaming stability (\%) of GC seeds powder as a function of $\mathrm{pH}$

\section{REFERENCES}

Abo El-Maati, M.F., S.M. Labib, A.M.A. AlGaby and M.F. Ramadan (2016). Antioxidant properties of different extracts of garden cress (lepidium sativum L.) Zagazig J. Agric. Res., 43 (5):1685-1697.

Ait-Yahia, O., F. Perreau, S. Bouzroura, Y. Benmalek, T. Dob and T. Belkebir (2018). Chemical composition and biological activities of nbutanol extract of Lepidium sativum L. (Brassicaceae) seed. Tropical J. Pharm. Res.,17 (5): 891-896.

Ali, R.F.M. (2013). Preparation and characterization of protein isolate and biodiesel from garden cress seed. Europ. J. Chem., 4 (2): 85-91.

AOAC (2005). Official Methods of Analysis of the Association of Official Analytical Chemists, 18th Ed. Gaithersburg, Maryland, USA, AOAC Int.

Arinola, S.O. and K. Adesina (2014). Effect of thermal processing on the nutritional, antinutritional, and antioxidant properties of Tetracarpidium conophorum (African walnut). J. Food Proct.
Balasubramanian, M. (2009). Nutritive Value of Indian Food", Nat. Inst. Nutr., ICMR, Hyderabad.

Bigoniya, P., C.S. Singh and A. Shukla (2011). Pharmacognostical and physicochemical standardization of ethnopharmacologically important seeds of Lepidium sativum Linn and Wrightia tinctoria $\mathrm{R} \mathrm{Br}$. Indian J. Nat. Prod. Res., 2 : 464-471.

Brigelius-Flohe, R., F.J. Kelly, J.T. Salonem, J. Neuzil, J.M. Zingg and A. Azzi (2002). The European perspective on vitamin E: Current knowledge and future research. Ame. J. Clin. Nutr., 76 : 703-716.

Bryan, R.M., N.S. Shailesh, K.W. Jill, F.V. Steven and L.E. Roque (2009): Composition and physical properties of cress (Lepidium sativum L.) and field pennycress (Thlaspi arvense L.) oils. Industrial Crops and Prod., 30: 199-205.

Chau, C.F. and Y.L. Huang (2003). Comparison of the chemical composition and physicochemical properties of different fibers prepared from the peel of Citrus sinensis L. cv. Liucheng. J. Agric. Food Chem., 51: 2615-2618. 
Dandge, P.B., P.J. Kasabe, P.N. Patil and D.D. Kamble (2012). Nutritional, elemental analysis and antioxidant activity of garden cress seeds. Int. J. Pharm. and Pharmaceutical Sci., 4 (3): 392-395.

Diwakar, B.T., P.K. Dutta, B.R Lokesh and K.A. Naidu (2010). Physicochemical Properties of garden cress (Lepidium sativum L.) Seed Oil. J. Ame. Oil Chem. Soc., 87: 539-548.

Diwakar, B.T., P.K. Dutta, B.R. Lokesh and K.A. Naidu (2008). Bioavailability and metabolism of n-3 fatty acid rich garden cress (Lepidium sativum) seed oil in albino rats. Prostaglandins Leukot Essent Fatty Acids, 78:123-130.

Doke, S. and M. Guha (2014). Garden cress (Lepidium sativum L.) seeds an important medicinal source. J. Nat. Prod. Plant Res., 4 (1): $69-80$

Doke, S.C. and R. Guha (2017). Quality assessment of sweet snack from garden cress (Lepidium sativum L.) seeds-An unexplored health grain. J. Food Proc., 42:1-6.

Dominick, S. and R. Derrick (2001). Theory and Problems of Statistics and Econometrics. $2^{\text {nd }}$ Ed. New York, 202.

Gaafar, A.M., A.A. Morsi and H.E. Elghamry (2013). Chemical, nutritional and biochemical studies of garden cress protein isolate. Nat. and Sci., 11 (2): 8-13.

Garau, M.C., S. Simal, C. Rossello and A. Femenia (2007). Effect of airdrying temperature on physicochemical properties of dietary fibre and antioxidant capacity of orange (Citrus aurantium v. Canoneta) by products. Food Chem., 104: 1014-1024.

Ghante, M.H., S.L. Badole and S.L. Bodhankar (2011). Health Benefits of Garden Cress (Lepidium sativum L.). In V.R. Preedy, R.R. Watson and V. B. Patel (Eds.), Nuts and seeds in health and disease prevention. London: Elsevier Press, 521-527.

Gokavi, S.S., N.G. Malleshi and M.R. Guo (2004). Chemical composition of garden cress (Lepidium sativum) seeds and its fractions and use of bran as a functional ingredient. Plant Food. Hum Nutr., 59: 105111.
Gopalan, C., B.V.R. Sastri, S.C. Balasubramanian, B.S.N. Rao, Y.G. Deosthale and K.C. Pant (2011). Nutritive value of Indian foods. Nat. Inst. Nutr. Hyderabad, India: Indian Council of Med. Res.

Goupy, P., M. Hugues, P. Biovin and M.J. Amiot (1999). Antioxidant composition and activity of barley (Hordeum vulgare L.) and malt extracts of isolated phenolic compounds. J. Sci. Food Agric., 79 : 1625-1634.

Gulcin, I., O.I. Kufrevioglu, M. Oktay and M.E. Buyukokuroglu (2004). Antioxidant, antimicrobial, antinuclear and analgesic activities of nettle (Urticadioica L.). J. Ethnopharmacol., 90: 205-215.

Goli, A.H., M. Barzegar and M.A. Sahari (2005). Antioxidant activity and total phenolic compounds of pistachio (Pistachia vera) hull extracts. Food Chem., 92 : 521525.

Hanato, T., H. Kagawa, T. Yasuhara and T. Okuda (1988). Two new flavonoids and other constituents in licorice root: Their relative astringency and radical scavenging effects. Chem. Pharm. Bull., 36: 2090-2097.

Heim, K.E., A.R. Taigliaferro and D.J. Bobilya (2002). Flavonoid antioxidants: chemistry, metabolism and structure-activity relationships. J. Nut. Biochem., 13 : 572-584.

Indumathy, R. and A. Aruna (2013). Free radical scavenging activities, total phenolic and flavonoid content of Lepidium sativum (Linn.). Int. J. Pharm. and Pharmaceutical Sci., 5 (4): 634-637.

Jain, T. and K. Grover (2017). Nutritional Evaluation of Garden Cress Chikki. Agri. Res. and Technol. Open. Access. J., 4 (2): 555-631.

Jayaprakasha, G.K., R.P. Singh and K.K. Sakariah (2001). Antioxidant activity of grape seed (Vitis vinifera) extracts on peroxidation models in vitro. Food Chem., $73: 285-290$.

Jeong, S.M., S.Y. Kim, D.R. Kim, K.C. Nam, D.U. Ahn and S.C. Lee (2004). Effect of seed roasting conditions on the antioxidant activity of defatted sesame meal extracts. Food Chem. Toxicol., 69:377-381. 
Malar, J.C., K. Anita, R.J. Singhc, J. Vanmathi, A. Balasubramaniand and K. Vasanthi (2014). Antioxidative activity of different parts of the plant Lepidium sativum Linn. Biotechnol. Rep., 3: 95-98.

Mohammed, A. (2012). Preparation and characterization of protein isolate and biodiesel from garden cress seed. Europ. J. Chem., 4 (2): 85-91.

Mohite, S.Y., D.B. Gharal, R.C. Ranveer, A.K. Sahoo and J.S. Ghosh (2012). Development of health drink enriched with processed Garden cress (Lapidium sativum L.) seeds. Ame. J. Food Technol., 7(9): 571-576.

Moskaug, J., H. Carlsen, M. Myhrstad and R. Blomhoff (2004). Molecular imaging of the biological effects of quercetin and quercetinrich foods. Mechanisms of Ageing and Dev., 125 (4): 315-324.

Namir, M., H. Siliha and M.F. Ramadan (2015). Fiber pectin from tomato pomace: characteristics, functional properties and application in low-fat beef burger. Food Measure. DOI 10.1007/s11694-015-9236-5.

Neto, V.T., N. Narain, J.B. Silvce and P.S. Bora (2001). Functional properties of heat processed cashew nut (Anarcarduim occidental L.) kernel protein isolate. Die Nahrung, 45 : 258-262.

Oktay, M., G. Ihami and O. Kufrevioglu (2003). Determination of in vitro antioxidant activity of fennel (Foeniculum vulgare) seed extracts. Lebens. Wissen. Tech., 36 (2): 263-271.

Panwar, H. and M. Guha (2014). Effect of processing on nutraceutical properties of garden cress (lepidium sativum L.) seeds. Int. J. Pharm. and Pharmaceutical Sci., 6 (7): 315 -318 .

Prakasha, G.K., R.P. Singh and K.K. Sakariah (2001). Antioxidant activity of grape seeds extracts on peroxidation models in vitro. Food Chem., 73 : 285-290.

Quettier, D.C., B. Gressier, J. Vasseur, T. Dine, C. Brunet, C. Luyckx, J.C. Cayin, F. Bailleul and F. Trotin (2000). Phenolic compounds and antioxidant activities of buckwheat (Fagopyrum esculentum Moench.) hulls and flour. J. Ethnopharmacol., 72: 35-42.
Sarkar, S., S. Datta and I. Ghosh (2014). Experimental studies on nutritional medicinal role of garden cress seed on animal and human. Int. J. Med. Chem. and Anal., 4: 4145.

Sathe, S.K. and D.K. Salunkhe (1981). Functional properties of the great northern bean (Phaseolus vulgaris) proteins. Emulsion, foaming, viscosity and gelation properties. J. Food Sci., 46 : 71-75.

Shail, D., K.N. Manjari and L.N. Gupta (2016). Nutritional importance of Lepidium sativum L. (Garden cress/ Chandrashoor): A Rev. J. Pharm. and Anal. Res., 5 (1): 152-160.

Sethiya, N., A. Trivedi and S. Mishra (2014). The total antioxidant content and radical scavenging investigation on 17 phytochemical from dietary plant sources used globally as functional food. Biomedicine and Preventive Nut., 4(3): 439-444.

Sharma, S. and N. Agarwal (2011). Nourishing and healing power of garden cress (Lepidium sativum Linn). Indian J. Nat. Prod. and Res., 2 (3): 292-297.

Škerget, M., P. Kotnik, M. Hadolin, A. RižnerHraš, M. Simonič and Z. Knez (2005). Phenols, proanthocyanidins, flavones and flavonols in some plant materials and their antioxidant activities. Food Chem., 89: 191198.

Sood, M. and D. Sharada (2002) Iron food supplement. Indian J. Paed., 69: 943-948.

Tiwari, P.N. and G.S. Kulmi (2004). Performance of Chandrasur (Lepidium sativum) under different levels of nitrogen and phosphorus. J. Med. Arom. Plant. Sci., 26: 479-481.

Tuncay, O., D. Esiyok, B. Yagmur and O.B. Bulent (2011). Yield and quality of garden cress affected by different nitrogen sources and growing period. Afr. J. Agric. Res., 6 : 608-617.

Yadav, Y.C., A. Jain, D.N. Srivastava and A. Jain (2011). Fracture healing activity of ethanolic extract of Lepidium sativum L. seeds in internally fixed rat's femoral osteotomy model. An Int. J. Pharmaceutical Sci., 2 (3): 244-253. 
Yu, J., M. Ahmedna and I. Goktepe (2005). Effects of processing methods and extraction solvents on concentration and antioxidant activity of peanut skin phenolics. Food Chem., 90: 199-206.

Zhu, Y.Y., L. Zhou, S.C. Jiao and L.Z. Xu (2011). Relationship between soy food intake and breast cancer in China. Asian Pac J. Cancer Prev., 12: 2837-40

Zia-Ul-Haq, M., S. Ahmad, L. Calani, T. Mazzeo, D. Del Rio, N. Pellegrini and D. De Feo (2012). Compositional study and antioxidant potential of Ipomoea hederacea Jacq. and Lepidium sativum L. seeds. Molec., 17: 10306-10321.

\section{الخواص الكيميائية والوظيفية لبــور حب الرشـــاد (Lepidium sativum L., GC)}

$$
\text { خلود حاتم عبد السلام - عباس عمر طليبة - جيهان عبد الله الثوربجي - شريف عيد النمر }
$$

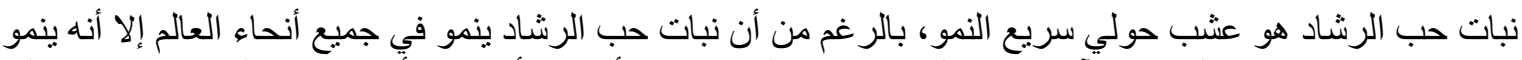

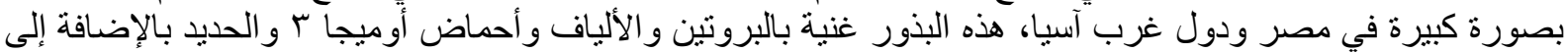

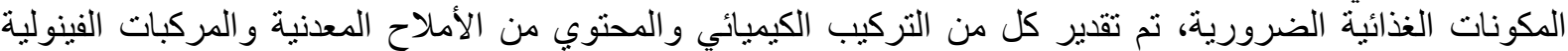

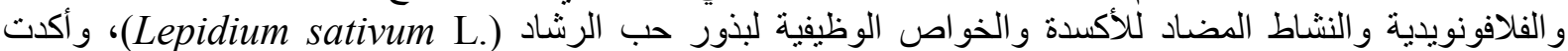

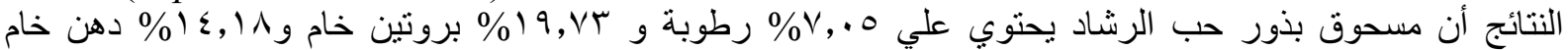

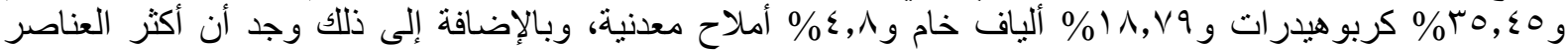

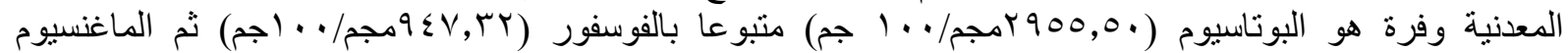

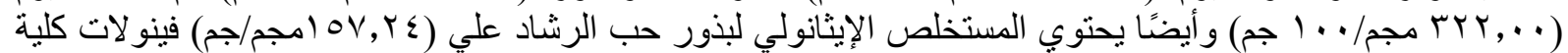

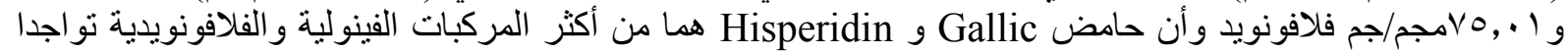

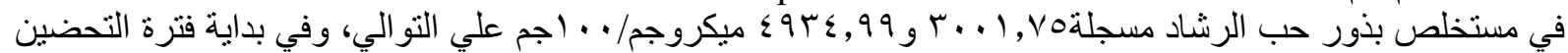

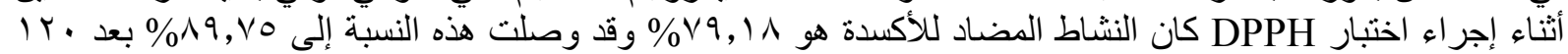

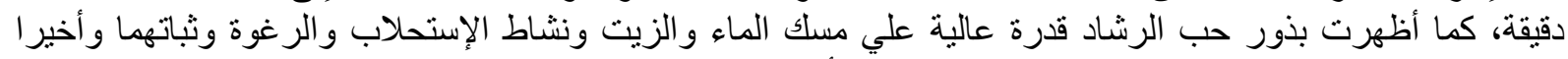

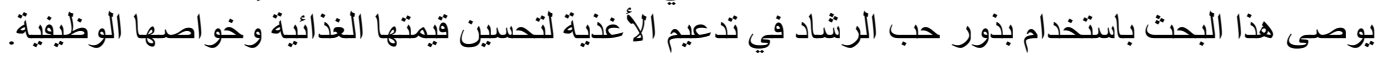

